\title{
Effects of recombinant growth hormone replacement and physical rehabilitation in recovery of gross motor function in children with cerebral palsy
}

\author{
This article was published in the following Dove Press journal: \\ Therapeutics and Clinical Risk Management \\ 26 November 2010 \\ Number of times this article has been viewed
}

\author{
Pedro Reimunde ${ }^{1,2}$ \\ Cristina Rodicio' \\ Natalia López' \\ Alba Alonso' \\ Pablo Devesa ${ }^{1,2}$ \\ Jesús Devesa ${ }^{1,2}$ \\ 'Medical Center "Proyecto Foltra", \\ Cacheiras (Teo), A Coruña; \\ ${ }^{2}$ Department of Physiology, School \\ of Medicine, University of Santiago \\ de Compostela, Spain
}

\begin{abstract}
Cerebral palsy is an important health issue that has a strong socioeconomic impact. There is no cure for cerebral palsy, and therapeutic approaches only report small benefits for affected people. In this study we assessed the effects of growth hormone treatment $(0.3 \mu \mathrm{g} / \mathrm{kg} / \mathrm{day})$ combined with physical rehabilitation in the recovery of gross motor function in children with growth hormone deficiency and cerebral palsy (four males and six females, mean age $5.63 \pm 2.32$ years) as compared with that observed in a similar population of cerebral palsy children (five males, five females, mean age $5.9 \pm 2.18$ years) without growth hormone deficiency treated only with physical rehabilitation for two months. The Gross Motor Function Measure (GMFM-88) and Modified Ashworth Scale were performed before commencing the treatment and after completion thereof. In children with cerebral palsy and growth hormone deficiency, Dimension A $(P<0.02)$, dimension B $(P<0.02)$, and dimension $\mathrm{C}(P<0.02)$ of the GMFM-88, and the total score of the test $(P<0.01)$ significantly improved after the treatment; dimension D and dimension $\mathrm{E}$ did not increase, and four of five spastic patients showed a reduction in spasticity. However, in children with cerebral palsy and without growth hormone deficiency, only the total score of the test improved significantly after the treatment period. This indicates that growth hormone replacement therapy was responsible for the large differences observed between both groups in response to physical rehabilitation. We propose that the combined therapy involving growth hormone administration and physical rehabilitation may be a useful therapeutic approach in the recovery of gross motor function in children with growth hormone deficiency and cerebral palsy.
\end{abstract}

Keywords: growth hormone, cerebral palsy, neural plasticity, neural regeneration, physical rehabilitation, gross motor function

\section{Introduction}

Cerebral palsy describes a group of disorders of the development of movement and posture, causing activity limitation, that are attributed to nonprogressive disturbances that occurred in the developing fetal or infant brain. The motor disorders of cerebral palsy are often accompanied by disturbances of sensation, cognition, communication, perception, and/or behavior, and/or by a seizure disorder. ${ }^{1}$ Cerebral palsy is the most common cause of physical disability in childhood. ${ }^{2}$ The estimated prevalence of cerebral palsy in the general population is $2 / 1000,{ }^{3}$ and the cumulative incidence rate of cerebral palsy in the age group 5-7 years is $2.7 / 1000 .{ }^{3}$ Major causes of cerebral palsy involve prematurity ( $40 \%-50 \%$ of cases), abnormal intrauterine development 
due to fetal-maternal infections, asphyxia during delivery, brain trauma during labor and delivery, and complications in the perinatal period. ${ }^{4}$ Independent of causal factors responsible for the development of cerebral palsy, the disease has a strong socioeconomic impact. ${ }^{5}$ Currently there is no cure for cerebral palsy, and the therapeutic approaches of physical therapy, occupational therapy, speech therapy, neuropsychology, pharmacology, and surgery achieve only partial benefits for affected individuals. ${ }^{3}$

It has been shown that children with cerebral palsy often have poor linear growth during childhood, resulting in a diminished final adult height, ${ }^{6}$ an issue that has received little attention so far. ${ }^{6-10}$ In the studies that have been reported, the investigators have demonstrated that children with cerebral palsy show cerebral palsy deficient growth hormone secretion, by using provocative tests for growth hormone, that insulin-like growth factor (IGF-1) and low growth hormone levels in children with cerebral palsy may explain their low height and that decreased plasma IGF-1 and IGF binding protein 3 (IGFBP3) levels are associated with osteopenia in children with cerebral palsy. ${ }^{6-10}$ We have previously shown that $70 \%$ of a population of 46 children with cerebral palsy lacked normal growth hormone secretion. ${ }^{3}$ Among the phenomena that could cause impaired growth hormone secretion are the presence of an altered pool of neurotransmitters, psychosocial deprivation, or suboptimal nutritional status. ${ }^{3}$

Neural plasticity and regeneration of the brain, in response to both neurologic injury and different neurological stimulations have been widely demonstrated in animal models ${ }^{11-14}$ and in clinical studies using imaging techniques, ${ }^{15-18}$ electrophysiologic assessments, ${ }^{19,20}$ and clinical tests. ${ }^{21-25}$ Moreover, it has been reported that the mechanisms of plasticity are increased in the developing central nervous system, so that children who suffer injury at this stage could achieve more complete recovery than adult patients. ${ }^{26}$

Several hormones play a role in the recovery from brain injuries, acting either on neurogenesis and/or neural plasticity. Among these, the growth hormone-IGF-1 system seems to be very important for inducing adult neurogenesis and increasing brain plasticity. ${ }^{3}$ Growth hormone and IGF-1 and their receptors are expressed locally in the brain $^{27-36}$ and both hormones can cross the blood-brain barrier. ${ }^{36}$ Thus, besides its role in several metabolic processes, it has been shown that the growth hormoneIGF-1 axis exerts multiple and important neurotrophic effects related to cell proliferation and survival, both in the central and peripheral nervous system. ${ }^{3,36}$ In fact, a number of studies have demonstrated that this endocrine axis induces strong proliferation of neural cell precursors in major neurogenic niches, under both physiologic and pathologic conditions. ${ }^{35,37-39}$ Moreover, growth hormone expression is increased in the affected brain hemisphere after an ischemic injury. ${ }^{40,41}$ On the other hand, we demonstrated, for the first time, that growth hormone is an important factor for cell survival. ${ }^{42}$ Thus, both growth hormone and IGF-1 display marked neuroprotective ${ }^{43,44}$ and antiapoptotic ${ }^{45-47}$ effects.

In a previous study we postulated that growth hormone replacement therapy might be useful in the treatment of children with cerebral palsy, not only for achieving a more normal height but also for correcting some of the neurologic disorders that these patients suffer. ${ }^{3}$ This study was designed to test this hypothesis, and evaluated the effects of growth hormone treatment combined with physical rehabilitation in the recovery of gross motor function in children with growth hormone deficiency and cerebral palsy as compared with the effects obtained in a similar population of cerebral palsy children without growth hormone deficiency and treated only with physical rehabilitation. Despite the fact that exercise is a powerful stimulus for pituitary growth hormone secretion, cerebral palsy children without growth hormone deficiency subjected to intense physical therapy rehabilitation do not achieve significant improvements. We studied the effects of growth hormone therapy in children with cerebral palsy and growth hormone deficiency as compared with those obtained in children with cerebral palsy and without growth hormone deficiency subjected to the same physical rehabilitation. The rationale for this was to test whether or not exogenous growth hormone administration plays a role in neurogenesis and/or brain plasticity.

\section{Method \\ Participants}

The study was conducted in 20 children with cerebral palsy, comprising nine males and 11 females, aged 4.0-10.5 years, who attended the Medical Center Proyecto Foltra for physical and cognitive rehabilitation, selected from a population of 46 cerebral palsy children. ${ }^{3}$ The reason for selecting 20 children from 46 was to achieve the best possible match between the groups with regard to age, gender, disabilities exhibited, and clinical history. The selection was made by the principal investigator, and none of the therapists knew whether or not the children selected had growth hormone deficiency. All patients were Level IV or V according to the Gross Motor Function Classification System. ${ }^{48}$ Ten of 
these cerebral palsy children had been previously detected to have growth hormone deficiency, ${ }^{3}$ and comprised the study group. The main characteristics of the patients in each group studied are shown in Tables 1 and 2.

\section{Treatment of growth hormone deficiency}

After obtaining informed consent from their parents, the children with cerebral palsy and growth hormone deficiency were given growth hormone (rhGH, Omnitrope ${ }^{\circledR}$, Sandoz) $0.3 \mu \mathrm{g} / \mathrm{kg} /$ day subcutaneously for five days per week at 10.30 pm for two months). Growth hormone administration commenced when physical rehabilitation started.

Blood sample analyses was performed for routine hematology and biochemistry parameters. Baseline anterior pituitary hormone secretion and plasma levels of free $\mathrm{T} 4$ were measured by chemiluminescence assays. In addition, fasting plasma IGF-1 and IGFBP3 were measured by solid-phase, enzyme-labeled chemiluminescent immunometric assay (Inmulite 2000, Siemens). These analyses were carried out before commencing the study and at the end of the study.

\section{Clinical assessment}

To assess motor function in our patients, we used a widely recognized test, the Gross Motor Function Measure (GMFM88). ${ }^{49}$ The GMFM- 88 is a scale constructed for evaluation of change in gross motor function in children with cerebral palsy. The GMFM- 88 consists of 88 items grouped into five dimensions, ie, dimension A (lying and rolling, 17 items), dimension B (sitting, 20 items), dimension $\mathrm{C}$ (crawling and kneeling, 14 items), dimension D (standing, 13 items) and dimension E (walking, running, and jumping, 24 items). Scores for each dimension are expressed as a percentage of the maximum score for that dimension, adding the scores for all dimensions, and dividing by 5 to obtain the total score. The reliability, validity, and responsiveness of the GMFM-88 scores are documented for children with cerebral palsy. ${ }^{50}$ We also used the Modified Ashworth Scale ${ }^{51}$ to measure spasticity in our spastic patients. The GMFM-88 and Modified Ashworth Scale were performed before commencing the treatment and after two months of treatment.

\section{Intervention}

All patients received physical rehabilitation, which was carried out for 45 minutes per day, five days per week, for two months. The therapy basically involved psychomotor and postural re-education based on neurodevelopmental reactions, phases, and processes (ie, neurodevelopmental therapy), and its contents were adapted to the specific needs of each patient, depending on the initial clinical assessment. In general, the treatment was aimed at normalizing muscle tone and improving normal postural reactions, postural control of head and trunk, balance, upper limb motor function, and mobility.

To avoid any kind of bias, each therapist was assigned to treat children having cerebral palsy with or without growth hormone deficiency, without knowing their growth hormone status. The Modified Ashworth scale of spasticity was analyzed by one of the physiotherapists who did not know the growth hormone status of the patient he was examining. Both groups of patients received the same type and duration of physical rehabilitation.

\section{Data analysis}

Pre- and post-treatment data from the GMFM-88 were compared using a nonparametric test for two related samples (Wilcoxon signed-rank test and Mann-Whitney $U$ test). Data from the Modified Ashworth Scale were analyzed descriptively.

Table I Main characteristics of control group patients

\begin{tabular}{|c|c|c|c|c|c|c|}
\hline Patient & $\begin{array}{l}\text { Age } \\
\text { (years) }\end{array}$ & Gender & CP cause & Radiologic findings & $\begin{array}{l}\text { Motor } \\
\text { impairment }\end{array}$ & $\begin{array}{l}\text { GMFCS } \\
\text { level }\end{array}$ \\
\hline I & 4.25 & $M$ & Postsurgical iatrogenic injury & Intense diffuse cerebral edema & Flaccid TP & V \\
\hline 2 & 4.5 & $\mathrm{~F}$ & Perinatal hypoxia & PVL & Spastic TP & $\mathrm{V}$ \\
\hline 3 & 5.75 & M & Perinatal hypoxia & Multiple hemorrhagic lesions in PV zone & Spastic TP & $\mathrm{V}$ \\
\hline 4 & 9 & $\mathrm{~F}$ & Perinatal hypoxia & Multiple hemorrhagic lesions in PV zone & Dystonic TP & $\mathrm{V}$ \\
\hline 5 & 4.5 & $\mathrm{~F}$ & Prenatal hypoxia & PVL & Spastic TP & $\mathrm{V}$ \\
\hline 6 & 4 & $M$ & Prematurity & PVL & Spastic TP & V \\
\hline 7 & 4.5 & M & Prematurity & PVL & Spastic TP & $\mathrm{V}$ \\
\hline 8 & 4.5 & $\mathrm{~F}$ & Perinatal hypoxia & PVL & Dystonic TP & V \\
\hline 9 & 7.5 & $M$ & Prematurity & PVL & Spastic TP & IV \\
\hline 10 & 10.5 & $\mathrm{~F}$ & Postsurgical iatrogenic injury & Diffuse cerebral edema & Dystonic TP & V \\
\hline
\end{tabular}

Abbreviations: F, female; GMFCS, Gross Motor Function Classification System; M, male; CP, cerebral palsy; PV, periventricular; PVL, periventricular leucomalacia; TP, tetraplegia. 
Table 2 Main characteristics of study group patients

\begin{tabular}{|c|c|c|c|c|c|c|}
\hline Patient & $\begin{array}{l}\text { Age } \\
\text { (years) }\end{array}$ & Sex & CP cause & Radiologic findings & $\begin{array}{l}\text { Motor } \\
\text { impairment }\end{array}$ & $\begin{array}{l}\text { GMFCS } \\
\text { level }\end{array}$ \\
\hline I & 4.5 & $\mathrm{~F}$ & Perinatal hypoxia & $\begin{array}{l}\text { Multiple hemorrhagic lesions in the } \\
\text { thalamus, basal ganglia, and PV region }\end{array}$ & Dystonic TP & $\mathrm{V}$ \\
\hline 2 & 4.5 & M & Prematurity & $\begin{array}{l}\text { PVL, nodular morphology due to PO } \\
\text { intraparenchymal hematomas }\end{array}$ & Spastic TP & $\mathrm{V}$ \\
\hline 3 & 4 & M & Post-surgical iatrogenic injury & $\begin{array}{l}\text { Decreased activity and volume in PO } \\
\text { cortex, bilateral PO ischemia, diffuse } \\
\text { cerebral edema }\end{array}$ & Flaccid TP & $\mathrm{V}$ \\
\hline 4 & 9.8 & M & Perinatal hypoxia & PVL & Dystonic TP & IV \\
\hline 5 & 6 & $\mathrm{~F}$ & Prenatal hypoxia & PVL & Dystonic TP & $\mathrm{V}$ \\
\hline 6 & 4 & $\mathrm{~F}$ & Prematurity; & PVL & Spastic TP & $\mathrm{V}$ \\
\hline 7 & 4.2 & M & Perinatal hypoxia & Multicystic encephalopathy & Spastic TP & $\mathrm{V}$ \\
\hline 8 & 4.5 & $\mathrm{~F}$ & Perinatal hypoxia & $\begin{array}{l}\text { Less differentiation of structures, intense } \\
\text { diffuse cerebral edema }\end{array}$ & Spastic TP & $\mathrm{V}$ \\
\hline 9 & 10.5 & $\mathrm{~F}$ & Prenatal ischemia & Ulegyria & Spastic TP & IV \\
\hline 10 & 4.3 & $\mathrm{~F}$ & Perinatal hypoxia & PVL, corpus callosum hypoplasia & Dystonic TP & $\mathrm{V}$ \\
\hline
\end{tabular}

Abbreviations: F, female; GMFCS, Gross Motor Function Classification System; M, male; CP, cerebral palsy; PV, periventricular; PVL, periventricular leucomalacia; PO, parieto-occipital; TP, tetraplegia.

\section{Results}

In the study group, combined treatment using rhGH and physical rehabilitation led to significant improvements in dimension A (lying and rolling, $P<0.02$ ), dimension $\mathrm{B}$ (sitting, $P<0.02$ ), dimension $\mathrm{C}$ (crawling and kneeling, $P<0.02)$, and the total score of the GMFM-88 $(P<0.01)$; dimension $\mathrm{D}$ (standing) and dimension $\mathrm{E}$ (walking, running, and jumping) did not increase (Figure 1B and Table 3). Moreover, four of five spastic patients showed a reduction in their spasticity as measured by the Modified Ashworth Scale (Table 4). However, no significant changes were observed in any of these dimensions in the control group, although the total score significantly increased in these children (Figure $1 \mathrm{~A}$ and Table 3 ), and their spasticity was not improved (data not shown).

The differences between the improvements achieved at the end of the two-month treatment period for both groups

A

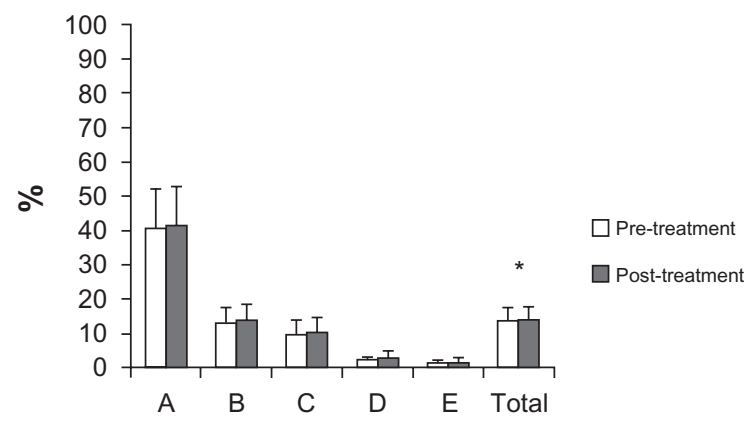

are shown in Figure 2 and Table 3. Clearly, as these data show, children with cerebral palsy and growth hormone deficiency achieved significant improvements in dimensions $\mathrm{A}, \mathrm{B}$, and $\mathrm{C}$, and in total score than the control children with cerebral palsy.

Growth hormone administration did not produce any secondary clinical effects. Plasma IGF-1 levels were not significantly different between the two groups of children at the end of the treatment period, and plasma cholesterol levels decreased significantly $(P<0.05)$ in children with cerebral palsy and growth hormone deficiency.

\section{Discussion}

Our results show that combined treatment using rhGH and physical rehabilitation leads to significant improvements in gross motor functions, including lying, rolling, sitting, crawling, and kneeling. All this tasks are contained in the

B

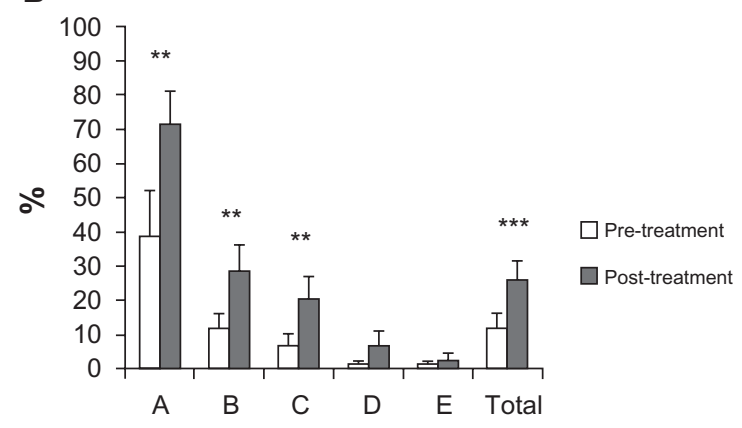

Figure I Clinical data from the GMFM-88.

Notes: A) Control group. B) Study group; "A", "B", "C", "D" and "E" in the horizontal axis are the different dimensions of the GMFM-88 and "TOTAL" is the total score of test. We show pre-treatment (white bars) and post-treatment (grey bars) means and standard errors for each specific assessment. Statistical significance was calculated from data obtained in the GMFM-88 before treatment and after 2 months of it (Wilcoxon signed-rank test) $(* P<0.05, * * P<0.02$ and $* * * P<0.01)$. 
Table 3 Results obtained from the GMFM-88

\begin{tabular}{|c|c|c|c|c|c|c|c|}
\hline GMFM-88 & Group & $\begin{array}{l}\text { Pretreatment } \\
\text { mean score } \\
\text { (SD) }\end{array}$ & $\begin{array}{l}\text { Post-treatment } \\
\text { mean score } \\
\text { (SD) }\end{array}$ & $\begin{array}{l}\text { Intragroup } \\
\text { significance } \\
\text { (Wilcoxon) }\end{array}$ & $\begin{array}{l}\text { Improvement } \\
\text { mean relative } \\
\text { to baseline (\%) }\end{array}$ & $\begin{array}{l}\text { Group's mean } \\
\text { rank (Mann- } \\
\text { Whitney) }\end{array}$ & $\begin{array}{l}\text { Intergroup } \\
\text { improvement } \\
\text { significance } \\
\text { (Mann- } \\
\text { Whitney) }\end{array}$ \\
\hline \multirow[t]{2}{*}{ Dimension A } & Control & $40.39(36.88)$ & 41.17 (36.98) & ns & 5.5 & 6.9 & $0.004 * * *$ \\
\hline & Study & 38.82 (37.63) & 71.76 (29.53) & $0.012 * *$ & 222.79 & 14.1 & \\
\hline \multirow[t]{2}{*}{ Dimension B } & Control & 13.16 (12.84) & $13.66(|2.5|)$ & ns & 15 & 6.8 & $0.002 * * *$ \\
\hline & Study & $12(13.46)$ & $29(22.67)$ & $0.012^{* *}$ & 13535.48 & 14.2 & \\
\hline \multirow[t]{2}{*}{ Dimension C } & Control & 9.52 (13.6) & $10.23(|3.5|)$ & ns & 15 & 6.75 & $0.002 * * *$ \\
\hline & Study & $6.9(\mathrm{II} .4 \mathrm{I})$ & 20.71 (19.95) & $0.012^{* *}$ & 33457.5 & 14.25 & \\
\hline \multirow[t]{2}{*}{ Dimension D } & Control & $2.05(2.91)$ & 3.07 (5.09) & ns & 20 & 11.55 & ns \\
\hline & Study & $\mathrm{I} .53(2.75)$ & $6.92(13.83)$ & ns & I5426.28 & 9.45 & \\
\hline \multirow[t]{2}{*}{ Dimension $\mathrm{E}$} & Control & I.25 (2.8I) & $\mathrm{I} .52(3.6 \mathrm{I})$ & ns & 0 & II.5 & ns \\
\hline & Study & $\mathrm{I} .25(2.8 \mathrm{I})$ & $2.77(6)$ & ns & 33.3 & 9.5 & \\
\hline \multirow[t]{2}{*}{ Total score } & Control & 13.27 (12.18) & $13.93(12.12)$ & $0.043^{*}$ & 10.24 & 14.8 & $0.001 * * *$ \\
\hline & Study & $12.10(12.25)$ & $26.23(16.1)$ & $0.005 * * *$ & 218.72 & 6.2 & \\
\hline
\end{tabular}

Notes: The different dimensions involved in the GMFM- 88 are shown in the first column. The fifth column shows the statistical significance from data obtained in the GMFM-88 before treatment compared with that two months after commencing it (Wilcoxon signed-rank test). The seventh and eighth columns show the group's mean rank and the statistical significance from the improvement mean relative to baseline (\%) (sixth column), comparing each group with the other (Mann-Whitney $U$ ). $* P<0.05$; $* * P<0.02 ; * * * P<0.01$.

Abbreviations: GMFM-88, gross motor function measure; SD, standard deviation; ns, not significant.

normal ontogeny of human movement, and are important to be able to perform daily activities. However, other gross motor functioning, such as standing, walking, running, and jumping did not improve. This could be due to the brief duration of treatment and the subjects' high level in the Gross Motor Function Classification System, such that they were not able to perform more complex motor tasks. Future studies with larger populations and a longer duration of treatment may be able to demonstrate differences in all motor functions tested.

Spasticity is defined as resistance to passive movement of the joints and is a key component of the so-called upper motor neuron syndrome. ${ }^{52}$ Spasticity, in its broadest clinical sense, has been linked to various motoneuronal, ${ }^{53}$ spinal,,${ }^{54}$ and supraspinal ${ }^{52,55}$ pathophysiologic phenomena. Thus, we can assume that the reduction in post-treatment spasticity in four of five spastic patients could be related to the efficacy of the treatment used to achieve normalization of the balance of supraspinal inhibitory and excitatory signals, ${ }^{52,55}$ of the secondary structural and functional changes that occur at

Table 4 Results obtained from the modified ashworth scale in spastic patients from the study group

\begin{tabular}{lll}
\hline Patient & Pretreatment & Post-treatment \\
\hline 2 & 2 & $\mathrm{I}+$ \\
6 & 3 & $\mathrm{I}+$ \\
7 & 4 & 3 \\
8 & 4 & 3 \\
9 & $\mathrm{I}+$ & $\mathrm{I}+$ \\
\hline
\end{tabular}

cellular level in the spinal cord itself below the level of the injury, ${ }^{54}$ and/or of the voltage-dependent persistent intrinsic motoneuronal inflows. ${ }^{53}$

The new physiotherapy concept, including whole body vibration, physiotherapy, resistance training, and treadmill training, without drug treatment for six months, had a significant and positive effect on bone mineral density, muscle force, and gross motor function in bilaterally spastic children with cerebral palsy. ${ }^{56}$ However, a systematic review did not find a statistically significant effect of

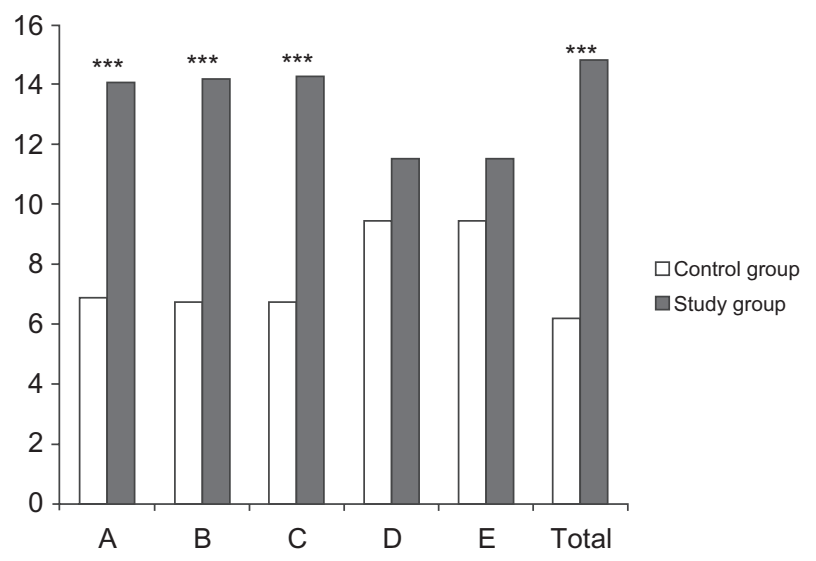

Figure 2 Study group improvements compared with control group improvements Notes: "A", "B", "C", " $D$ " and "E" in the horizontal axis are the different dimensions of the GMFM- 88 and "TOTAL" is the total score of tet test; we show the group's mean rank from Mann-Whitney $U$ for control (white bars) and study (grey bars) groups. Statistcal significance was calculated from the percentage of improvement over baseline for each of the dimensions evaluated in the GMFM-88, comparing groups with each other (Mann-Whitney $U)(* * * P<0.01)$. 
partial bodyweight-supported treadmill training in children with cerebral palsy, despite improvements in gross motor function. ${ }^{57}$ In a review of randomized controlled trials on physical therapy interventions in children with cerebral palsy, it was shown that some methods (such as neurodevelopmental therapy) were moderately effective in improving motor function in the upper extremities, walking speed, and stride amplitude. However, conflicting evidence was found for the effect of strength training on gross motor function. ${ }^{58}$ Similarly, a meta-analysis of randomized trials demonstrated that muscle strengthening had a small statistically significant, but not clinically meaningful, effect on gross motor function. ${ }^{59}$

On the other hand, some studies have described the effects of growth hormone replacement in children with cerebral palsy. However, most of them have only reported growth data and have not assessed any possible functional recovery. $6,7,60$

To our knowledge, this study is the first to demonstrate the positive effects of growth hormone administration in the recovery of some motor functions in children with cerebral palsy. Despite the fact that these were observed in children with cerebral palsy and growth hormone deficiency, because plasma IGF-1 values were similar in both groups at the end of the treatment period, it seems clear that exogenous administration of growth hormone was responsible for the effects observed. According to plasma IGF values, growth hormone status was similar in both groups at the end of the treatment period. In this regard, exercise is known to be a powerful stimulus for endogenous growth hormone release, and it has been demonstrated that inhibiting PI3-Akt signaling, one of the pathways by which growth hormone acts, ${ }^{42}$ blocks exercise-mediated enhancement of adult neurogenesis and synaptic plasticity in rats. ${ }^{61}$ This may explain the lack of positive effects obtained in children undergoing exhaustive daily physical work, perhaps because possible growth hormone deficiency has not been determined or treated. On the other hand, it has been recently demonstrated that exogenous growth hormone administration induces strong cellular proliferation in rodents with growth hormone deficiency. ${ }^{62}$ The data observed in our study support our hypothesis about the effects of growth hormone administration.

Thus, we conclude that combined therapy involving growth hormone replacement and physical rehabilitation is a useful therapeutic approach in the recovery of gross motor function in children with cerebral palsy and growth hormone deficiency. We are now carrying out larger and longer studies that will allow us to understand more precisely the effects of hormone treatment on children with cerebral palsy, aimed at improving both endocrine and neurologic disorders in children with cerebral palsy with or without growth hormone deficiency.

\section{Acknowledgment}

This study was supported by Foundation Foltra.

\section{Disclosure}

The authors report no conflicts of interest in this work.

\section{References}

1. Bax M, Goldstein M, Rosenbaum P, et al. Proposed definition and classification of cerebral palsy. Dev Med Child Neurol. 2005;47(8): 571-576.

2. Kerem Gunel M. Rehabilitation of children with cerebral palsy from a physiotherapist's perspective. Acta Orthop Traumatol Turc. 2009; 43(2):173-180. Turkish.

3. Devesa J, Devesa P, Reimunde P. Growth hormone deficiency and cerebral palsy. Ther Clin Risk Manag. 2010;6:413-418.

4. Krageloh-Mann I, Cans C. Cerebral palsy update. Brain Dev. 2009; 31(7):537-544.

5. Kruse M, Michelsen SI, Flachs EM, Bronnum-Hansen H, Madsen M, Uldall P. Lifetime costs of cerebral palsy. Dev Med Child Neurol. 2009; 51(8):622-628.

6. Shim ML, Moshang T Jr, Oppenheim WL, Cohen P. Is treatment with growth hormone effective in children with cerebral palsy? Dev Med Child Neurol. 2004;46(8):569-571.

7. Coniglio SJ, Stevenson RD. Growth hormone deficiency in two children with cerebral palsy. Dev Med Child Neurol. 1995;37(11): 1013-1015.

8. Coniglio SJ, Stevenson RD, Rogol AD. Apparent growth hormone deficiency in children with cerebral palsy. Dev Med Child Neurol. 1996; 38(9):797-804.

9. Ali O, Shim M, Fowler E, Cohen P, Oppenheim W. Spinal bone mineral density, IGF-1 and IGFBP-3 in children with cerebral palsy. Horm Res. 2007;68(6):316-320.

10. Kuperminc MN, Gurka MJ, Houlihan CM, et al. Puberty, statural growth, and growth hormone release in children with cerebral palsy. J Pediatr Rehabil Med. 2009;2(2):131-141.

11. Kleim JA, Lussnig E, Schwarz ER, Comery TA, Greenough WT. Synaptogenesis and fos expression in the motor cortex of the adult rat after motor skill learning. J Neurosci. 1996;16(14):4529-4535.

12. Nudo RJ, Milliken GW, Jenkins WM, Merzenich MM. Use-dependent alterations of movement representations in primary motor cortex of adult squirrel monkeys. J Neurosci. 1996;16(2):785-807.

13. Jones TA, Chu CJ, Grande LA, Gregory AD. Motor skills training enhances lesion-induced structural plasticity in the motor cortex of adult rats. J Neurosci. 1999;19(22):10153-10163.

14. Biernaskie J, Corbett D. Enriched rehabilitative training promotes improved forelimb motor function and enhanced dendritic growth after focal ischemic injury. $J$ Neurosci. 2001;21(14):5272-5280.

15. Marshall RS, Perera GM, Lazar RM, Krakauer JW, Constantine RC, DeLaPaz RL. Evolution of cortical activation during recovery from corticospinal tract infarction. Stroke. 2000;31(3):656-661.

16. Nelles G, Jentzen W, Jueptner M, Muller S, Diener HC. Arm training induced brain plasticity in stroke studied with serial positron emission tomography. Neuroimage. 2001;13(6 Pt 1):1146-1154.

17. Carey JR, Kimberley TJ, Lewis SM, et al. Analysis of fMRI and finger tracking training in subjects with chronic stroke. Brain. 2002; 125(Pt 4):773-788. 
18. Johansen-Berg H, Dawes H, Guy C, Smith SM, Wade DT, Matthews PM. Correlation between motor improvements and altered fMRI activity after rehabilitative therapy. Brain. 2002;125(Pt 12):2731-2742.

19. Liepert J, Miltner WH, Bauder H, et al. Motor cortex plasticity during constraint-induced movement therapy in stroke patients. Neurosci Lett. 1998;250(1):5-8.

20. Liepert J, Uhde I, Graf S, Leidner O, Weiller C. Motor cortex plasticity during forced-use therapy in stroke patients: A preliminary study. J Neurol. 2001;248(4):315-321.

21. Behrman AL, Bowden MG, Nair PM. Neuroplasticity after spinal cord injury and training: An emerging paradigm shift in rehabilitation and walking recovery. Phys Ther. 2006;86(10):1406-1425.

22. Daly JJ, Ruff RL. Construction of efficacious gait and upper limb functional interventions based on brain plasticity evidence and model-based measures for stroke patients. Scientific World Journal. 2007; 7:2031-2045.

23. Dunlop SA. Activity-dependent plasticity: Implications for recovery after spinal cord injury. Trends Neurosci. 2008;31(8):410-418.

24. Langhorne P, Coupar F, Pollock A. Motor recovery after stroke: A systematic review. Lancet Neurol. 2009;8(8):741-754.

25. Rensink M, Schuurmans M, Lindeman E, Hafsteinsdottir T. Task-oriented training in rehabilitation after stroke: Systematic review. J Adv Nurs. 2009;65(4):737-754.

26. Johnston MV. Plasticity in the developing brain: Implications for rehabilitation. Dev Disabil Res Rev. 2009;15(2):94-101.

27. Gossard F, Dihl F, Pelletier G, Dubois PM, Morel G. In situ hybridization to rat brain and pituitary gland of growth hormone cDNA. Neurosci Lett. 1987;79(3):251-256.

28. Araujo DM, Lapchak PA, Collier B, Chabot JG, Quirion R. Insulin-like growth factor-1 (somatomedin-C) receptors in the rat brain: Distribution and interaction with the hippocampal cholinergic system. Brain Res. 1989;484(1-2):130-138.

29. Werther GA, Abate M, Hogg A, et al. Localization of insulin-like growth factor-I mRNA in rat brain by in situ hybridization - relationship to IGF-I receptors. Mol Endocrinol. 1990;4(5):773-778.

30. Lai ZN, Emtner M, Roos P, Nyberg F. Characterization of putative growth hormone receptors in human choroid plexus. Brain Res. 1991; 546(2):222-226

31. Lobie PE, Garcia-Aragon J, Lincoln DT, Barnard R, Wilcox JN, Waters MJ. Localization and ontogeny of growth hormone receptor gene expression in the central nervous system. Brain Res Dev Brain Res. 1993;74(2):225-233.

32. Aguado F, Rodrigo J, Cacicedo L, Mellstrom B. Distribution of insulin-like growth factor-I receptor mRNA in rat brain. Regulation in the hypothalamo-neurohypophysial system. J Mol Endocrinol. 1993; 11(2):231-239

33. D'Ercole AJ, Ye P, Calikoglu AS, Gutierrez-Ospina G. The role of the insulin-like growth factors in the central nervous system. Mol Neurobiol. 1996;13(3):227-255.

34. Chung YH, Shin CM, Joo KM, Kim MJ, Cha CI. Region-specific alterations in insulin-like growth factor receptor type I in the cerebral cortex and hippocampus of aged rats. Brain Res. 2002;946(2):307-313.

35. Aberg MA, Aberg ND, Palmer TD, et al. IGF-I has a direct proliferative effect in adult hippocampal progenitor cells. Mol Cell Neurosci. 2003; 24(1):23-40.

36. Aberg ND, Brywe KG, Isgaard J. Aspects of growth hormone and insulin-like growth factor-I related to neuroprotection, regeneration, and functional plasticity in the adult brain. Scientific World Journal. 2006;18(6):53-80.

37. Aberg MA, Aberg ND, Hedbacker H, Oscarsson J, Eriksson PS. Peripheral infusion of IGF-I selectively induces neurogenesis in the adult rat hippocampus. J Neurosci. 2000;20(8):2896-2903.

38. Christophidis LJ, Gorba T, Gustavsson M, et al. Growth hormone receptor immunoreactivity is increased in the subventricular zone of juvenile rat brain after focal ischemia: A potential role for growth hormone in injury-induced neurogenesis. Growth Horm IGF Res. 2009; 19(6):497-506.
39. Aberg ND, Johansson I, Aberg MA, et al. Peripheral administration of $\mathrm{GH}$ induces cell proliferation in the brain of adult hypophysectomized rats. J Endocrinol. 2009;201(1):141-150.

40. Beilharz EJ, Russo VC, Butler G, et al. Co-ordinated and cellular specific induction of the components of the IGF/IGFBP axis in the rat brain following hypoxic-ischemic injury. Brain Res Mol Brain Res. 1998; 59(2):119-134.

41. Gustafson K, Hagberg H, Bengtsson BA, Brantsing C, Isgaard J. Possible protective role of growth hormone in hypoxia-ischemia in neonatal rats. Pediatr Res. 1999;45(3):318-323.

42. Costoya JA, Finidori J, Moutoussamy S, Señaris R, Devesa J, Arce VM. Activation of growth hormone receptor delivers an antiapoptotic signal: Evidence for a role of akt in this pathway. Endocrinology. 1999;140(12):5937-5943.

43. Scheepens A, Williams CE, Breier BH, Guan J, Gluckman PD. A role for the somatotropic axis in neural development, injury and disease. J Pediatr Endocrinol Metab. 2000;13 Suppl 6:1483-1491.

44. Scheepens A, Sirimanne ES, Breier BH, Clark RG, Gluckman PD, Williams CE. Growth hormone as a neuronal rescue factor during recovery from CNS injury. Neuroscience. 2001;104(3):677-687.

45. Shin DH, Lee E, Kim JW, et al. Protective effect of growth hormone on neuronal apoptosis after hypoxia-ischemia in the neonatal rat brain. Neurosci Lett. 2004;354(1):64-68.

46. Guan J, Williams C, Gunning M, Mallard C, Gluckman P. The effects of IGF-1 treatment after hypoxic-ischemic brain injury in adult rats. J Cereb Blood Flow Metab. 1993;13(4):609-616.

47. Guan J, Bennet L, George S, et al. Insulin-like growth factor-1 reduces postischemic white matter injury in fetal sheep. J Cereb Blood Flow Metab. 2001;21(5):493-502.

48. Palisano R, Rosenbaum P, Walter S, Russell D, Wood E, Galuppi B. Development and reliability of a system to classify gross motor function in children with cerebral palsy. Dev Med Child Neurol. 1997;39(4): 214-223.

49. Russell DJ, Avery LM, Rosenbaum PL, Raina PS, Walter SD, Palisano RJ. Improved scaling of the gross motor function measure for children with cerebral palsy: Evidence of reliability and validity. Phys Ther. 2000;80(9):873-885.

50. Palisano RJ, Hanna SE, Rosenbaum PL, et al. Validation of a model of gross motor function for children with cerebral palsy. Phys Ther. 2000; 80(10):974-985.

51. Bohannon RW, Smith MB. Interrater reliability of a modified Ashworth scale of muscle spasticity. Phys Ther. 1987;67(2):206-207.

52. Sheean G. The pathophysiology of spasticity. Eur J Neurol. 2002; 9 Suppl 1:3-9.

53. Gorassini MA, Knash ME, Harvey PJ, Bennett DJ, Yang JF. Role of motoneurons in the generation of muscle spasms after spinal cord injury. Brain. 2004;127(Pt 10):2247-2258.

54. Nielsen JB, Crone C, Hultborn H. The spinal pathophysiology of spasticity - from a basic science point of view. Acta Physiol (Oxf). 2007;189(2):171-180.

55. Dietz V. Supraspinal pathways and the development of muscle-tone dysregulation. Dev Med Child Neurol. 1999;41(10): $708-715$.

56. Stark C, Nikopoulou-Smyrni P, Stabrey A, Semler O, Schoenau E. Effect of a new physiotherapy concept on bone mineral density, muscle force and gross motor function in children with bilateral cerebral palsy. J Musculoskelet Neuronal Interact. 2010;10(2): $151-158$.

57. Mutlu A, Krosschell K, Spira DG. Treadmill training with partial body-weight support in children with cerebral palsy: A systematic review. Dev Med Child Neurol. 2009;51(4):268-275.

58. Anttila H, Autti-Ramo I, Suoranta J, Makela M, Malmivaara A. Effectiveness of physical therapy interventions for children with cerebral palsy: A systematic review. BMC Pediatr. 2008;8:14.

59. Scianni A, Butler JM, Ada L, Teixeira-Salmela LF. Muscle strengthening is not effective in children and adolescents with cerebral palsy: A systematic review. Aust J Physiother. 2009;55(2): $81-87$ 
60. Ali O, Shim M, Fowler E, et al. Growth hormone therapy improves bone mineral density in children with cerebral palsy: A preliminary pilot study. J Clin Endocrinol Metab. 2007;92(3):932-937.

61. Bruel-Jungerman E, Veyrac A, Dufour F, Horwood J, Laroche S, Davis S. Inhibition of PI3-Akt signaling blocks exercise-mediated enhancement of adult neurogenesis and synaptic plasticity in the dentate gyrus. PloS One. 2009;4(11):e7901.
62. David Aberg N, Lind J, Isgaard J, Georg Kuhn H. Peripheral growth hormone induces cell proliferation in the intact adult rat brain. Growth Horm IGF Res. 2010;20(3):264-269.

\section{Publish your work in this journal}

Therapeutics and Clinical Risk Management is an international, peerreviewed journal of clinical therapeutics and risk management, focusing on concise rapid reporting of clinical studies in all therapeutic areas, outcomes, safety, and programs for the effective, safe, and sustained use of medicines. This journal is indexed on PubMed Central, CAS,
EMBase, Scopus and the Elsevier Bibliographic databases. The manuscript management system is completely online and includes a very quick and fair peer-review system, which is all easy to use. Visit http://www.dovepress.com/testimonials.php to read real quotes from published authors.

Submit your manuscript here: http://www.dovepress.com/therapeutics-and-clinical-risk-management-journal 